Issue no. $27 / 2018$

\title{
THE VALIDITY OF VALUE-BASED CONSUMER BEHAVIORAL MODELS IN THE FINANCIAL CONSCIOUSNESS OF THE Z GENERATION
}

\author{
Assoc. Prof. Dr. Mónika Garia-Fodor \\ Óbuda University, Keleti Faculty of Business and Management, Hungary \\ fodor.monika@kgk.uni-obuda.hu \\ Assoc. Prof. Dr. habil. Ágnes Csiszárik-Kocsír \\ Óbuda University, Keleti Faculty of Business and Management, Hungary \\ kocsir.agnes@,kgk.uni-obuda.hu
}

DOI:10.24193/OJMNE.2018.27.05

\begin{abstract}
:
The theoretical background of our study is based on three bases: one of the pillars is value-based consumer behavior models, the other is generation marketing, and the third is financial culture and financial competence. The purpose of our research was to investigate whether the basic context of value-based consumer behavior theory - that is, the relationship between individual value orientation and the exact consumer decision - is valid in the context of money-related decisions. In addition to the relevant secondary sources, we use primary research results in quantitative data collection. The focus was on young people ( $Y$ and $Z$ generations). Our choice has fallen to these two target groups because we believe that exploring young people's money-related knowledge and understanding their financial decisions has useful information for financial service providers, as they are about the potential of their target markets. The values and the way of thinking of the chosen generations are distinct from the previous generations. That is why we think that instead of standard solutions, choosing a differentiated toolkit can be a successful solution to develop the financial culture and successfully position financial services. In addition, the results of the research can also show the direction of those involved in education, how to improve the financial knowledge of young people, how to shape their attitude towards money efficiently and target-oriented.
\end{abstract}

Keywords: value-based behavioral model, financial consciousness. 
Issue no. $27 / 2018$

\section{Literature review}

As previously mentioned, the theoretical background of the study is based on three pillars. Systematically following this logic, focusing on the three bases, presenting the relevant literature background.

\subsection{A value-based approach to consumer behavior}

Consumer behavior is defined by value trends in the longer term. It can also be interpreted as an external aspect of the value system of the individual's consumer andconsumer decisions. While examining consumer's habits, we can't ignore the changes in lifestyle and value system. It is no coincidence that sociological and anthropological theories are the starting points for many marketing researches, providing a basis for exploring the inner context of the factors that determine consumer confidence. The value system analysis has a decisive role in exploring the internal context of consumer behavior, it is no coincidence that methods were used in the 1960s, consumer behavioral analysis were built on the basic contexts of lifestyle and value systems, think only of AIO or VALSI and VALSII methods (Veres, 2004).

According to the interdisciplinary approach of consumer behavior, the value system is linked to two environmental elements, cultural and social factors. Every society within its own borders develops a value and pre-emptive system of its culture that defines the behavior to be followed within its boundaries. For social factors, value can be linked to lifestyle, standrad of living and status dimensions. Sociological and consumption sociological approaches show a difference in terms of the importance of cultural, social or individual determinism of the value (Hofmeister-Tóth, 2003; Andorka, 2003; Giddens, 2003; HawkinsBest-Coney, 1992).

In our opinion, based on theories, everyone can determine the culture of a given group, but group values are influenced by the determining circumstances and circumstances of everyday life. Among the valuation methods used in psychology one of the best-known in marketing science is the Rokeach Value System (1973 in Horváth, 1996) and Mitchell's "Values and Value Styles" (1983 in Horváth, 1996).The list of Kahle's values (Kahle, 1985) is already well-suited to consumer behavioral research adapting to the characteristics of market research (Hofmeister-Tóth, 2003). Value-measurement methods play an important 
role in expanding the toolkit of marketing research to give them the opportunity to analyze the consumer's preference and how the customer's decision-making is based. With some kind of further consideration of the value-measurement methods, values-based consumer behavior models were based on the value measurements made possible by the above mentioned methods. Based on the measurement of these values, these models were intended to explain the motives for product and service selection.

Value-based consumer behavior theories (Horváth, 1996; Grunert, 1996 in Lehota 2001) have a common feature and assume a relationship between the consumer's choice of product and service choice and the value system. The essence of the mechanism of action is that on the first level where the consumer's general values lies, is peace, security and time. On the second level, lies the values that determine consumer habits, such as quality consciousness, hedonism and time awareness. Finally, on the third level, you can find the specific product and service values, such as the motives of the product and service choice. The basic concept of these theories inspired us to extend the relationship between value system and consumer behavior to financial competencies and to analyze money-related decisions, and validate the existence of a relationship between individual value orientation and financial decisions (awareness) in the case of $\mathrm{Z}$ and $\mathrm{Y}$ generations.

\section{The significance of generation marketing, the characteristics of $Y$ and $Z$} generations

The difference between generations as a segmentation criterion can be successfully applied in many areas of marketing. The reason for this is that the generations can be characterized very well along the common values that are expressly assigned to them. Values, common experiences, the identities that make it possible for them to characterize a generation, since these attributes connect people, they represent a kind of organizing principle between a variety of individual fates, stories, and characteristics. Identities within generations frame the decisions of the people who belong there and also distinguish them from other generations (Törőcsik, 2003).

An important aspect of the behavioral analysis of generations is the evaluation of value orientation and the determination of its differences (Schewe, Noble 2000). The essence 
Issue no. $27 / 2018$

of the concept is that, beside from the strict limitation of age, it need to be considered that individuals belonging to each generation have a distinctly different group experience. According to Howe and Strauss (2000) three factors can be highlighted that defines generations beyond the age:

- perceived membership - self-perception of membership that begins with adolescence and is completed in adulthood;

- common beliefs and behaviors - with family, career, private life, politics, religion, etc. related attitudes and behavior;

- a common place in history - the turning points of historical trends and the major events that affect the generation in decisive years.

The starting point of a marketing approach based on the generation theory is that the major and decisive events experienced during socialization, the "zeitgeist" accompany people to the end of their lives and have an impact on their choices. In our study, we focus on $\mathrm{Y}$ and $\mathrm{Z}$ consumers, so we briefly describe these generations.

\section{"Y-generation"}

They are the first wave of the digital generation, and in their private lives, the internet is used daily. The X-Generation is a serious challenge for the job market because they represent a qualitatively new level compared to the messenger generation. Shaming our ancestors they confront the old rules, and have whole different abilities than the previous generations. According to esoteric literature, they have a mission: the task of the generation is to open up the spiritual eye of humanity and to create a critical mass that is responsible for launching changes. They grew up with computers, are very practical and use the internet very well. The Y generation already transform and shape the workplace into its own image. The millennium generation wants to enjoy the job: let it be modern, with a large room and a kitchen that allows common dinings and conversations.

\section{"Z-generation"}

The members of the Z-generation - the target group of our primary research project have been fully integrated into the world, which is increasingly determined by the various digital technologies: they are the IT or Digital X (DX) generations. The Z-generation, which started working in the early years of the 21 st century, is characterized by rapid changes. 
Issue no. $27 / 2018$

Named not by accident the English word "zappers", that is, "catching, jumping". They live in a much faster rhythm than their predecessors, and if they do not like something - like a job the're ready for immediate changes. Compared to their predecessors, they represent a completely different world: modern techniques, information technology, and the online world have become adults with them and become part of their personality. They live their social relationships at the same time in the real world and in the virtual world as well. For them, it is self-evident that their everyday communication, emotional, social life, creativity and playfulness are shared by the mobile phone, internet and the digital assets, shared with each other and with the widest public (Facebook, Twitter, Instagram, etc.) The members of the digital $\mathrm{X}$ practically never knew the world without internet, telecommunication and television. Do they therefore struggle with the lack of interpersonal skills and are unable to actively listen?

\subsection{The relationship between financial culture and $\mathrm{Z}$ generation}

Nearly ten years after the economic crisis, it became a part of our lives to learn finance, money and related knowledge. The banking and lending practices before the crisis in 2008 have just been refuted this, it was suggested contrary to the definition of demand, that the willingness to consume is enough and the ability will be given by the bank. This practice used that the people weren't financially educated, haven't got the required financial knowledge that would have been necessary to make the right choices. However, the margins of financial culture and literacy have to remember ethical and moral issues, or rather the total denial of ethical and moral principles, which made it possible to exploit complainant with a poor financial culture (Csiszárik-Kocsir, 2016). The crisis and the subsequent events drew attention to the deficiency associated with financial knowledge (Klapper - Lusardi - Panos, 2012). Before the crisis due to general welfare and unlimited liquidity, some groups were socialized as they haven't learnt to handle and allocate their money, because that message come from everywhere, that they can replace their lack of liquidity with loans. Before the crisis, Johnson and Sherraden (2007) have already pointed out that it would be expedient to involve the younger generation in the preparation of financial processes by extending the subjects taught in financial terms or even by involving family financial decisions. A similar view was already made by Osana, Tucker and Bennett (2003), as this could lead to greater 
Issue no. $27 / 2018$

financial responsibility. Irresponsibly borrowed, early, unreasonable consumption, either indirectly or directly, but can be linked to financial culture and the lack of financial culture. Examining financial culture has become an increasingly fashionable concept and research area. Numerous articles, research, thesis and diploma work deal with it, but exact, tangible steps have not really been made in the direction of development. Each major bank mentions the development of financial culture as part of CSR's activities, but notable results haven't been found yet.

A common definition of financial culture has not happened yet.If we look at it in a narrower sense, financial culture is in fact a financial literacy and ability, which requires special, professional knowledge. According to the generally accepted definition, "a level of financial knowledge and skills that enables individuals to identify the essential financial information necessary for their conscious and prudent decisions, and then, after obtaining them, To interpret them and decide on this, assessing their possible future financial and other consequences "(MNB - HFSA, 2008). Based on the definition of Atkinson and Messy (2012), financial culture is a combination of knowledge, skills, abilities, attitudes and behavior patterns that are essential for good financial decision on both individual and social levels. With the possession of financial literacy, wealth can be raised and improved, which can be felt not only on the micro but also on the macro level. According to Luxander and his coauthors (2014), financial culture is the ability to process financial information and make good financial decisions. Suganya, Sakthivelrani and Durai (2013) formulate the essence of financial culture as a set of knowledge that enables individuals to maximize their financial longevity of life. Ultimately, financial culture always means a combination of abilities and skills that can be used to increase individual and social well-being. This is unthinkable in the absence of specific professional knowledge, so it can be stated that the role of financial education is unmissable and unavoidable on the subject.

Knowledge, knowing and understanding modern financial processes and adapting to change, is indispensable in today's globalized world. That is why Grifoni and Messy (2012) formulate the essence of the concept as an indispensable skill nowadays. Financial culture can be divided into parts as there are developmentable and less developmentable levels. Developable levels include those elements of financial culture that can be modified easily and 
Issue no. $27 / 2018$

in a relatively short time by education and training. These include financial knowledge, financial skills and abilities. The difficult parts of financial culture can be captured in traditions, customs, different seen and learned norms, views and values (Balázsné, 2013). The latter, the line from parents, families and friends, can be most difficult to shape, since this is a part of our socialization, it is embedded in our character, so it is accompanied by our lives (Koh-Lee, 2010). This process is called economic socialization, where the young adult generation learns from the educators the principles of using money, and acquires the attitudes that will be determined later on in the broader terms of success or failure in the financial world. In this process, the family has a prominent role in teaching the principles of money management and usage that are decisive for them (Zsótér - Nagy, 2012). All this is related to the opinions that have already been made, that financial awareness should be started early in school age so that any negative habits can be corrected somewhat.

It is not easy to judge the financial culture of an economy and society, but it can also be said that in this global financial world, the measurement of this area is a reference to the culture of individuals in the economy and society. (Bárczi - Zéman, 2015). There are some researches that link financial culture with financial knowledge, others link financial attitudes, financial literacy, and financial knowledge. There is no unified view of who is responsible for developing this area. According to some opinions, financial literacy has to be developed in primary education, while other opinions say that this is only the responsibility of the high school. Financial culture or financial awareness involves appropriate and applicable levels of financial knowledge, that is, material knowledge, complementing it with concrete counting and arithmetical questions.

The development of the financial culture of students currently entering higher education is the main priority. They are part of the $\mathrm{Z}$ generation, who live most of their lives virtually, based on the Internet Traditional education and administration is a burden for them, they prefer electronic channels instead of printed sources of information. These young people are also the main target groups of the digitizing banking system, the fintech innovations. As we see it in everyday life, there is a paradigm shift in the financial sector (Kerényi - Molnár, 2017). With the increasing spread of digitization, the advancement of the Internet, the widespread use of mobile communications and the constant lack of time, young people are no 
Issue no. $27 / 2018$

longer willing to stand in the bank because of a simple administration. They are thinking in applications and wanting to do their business electronically, so they want to go banking electronically (mobile phones) (Menon, 2016), as the Z generations are already born with "mobile phones in their hands". As you can see the adverse effects of the process in traditional human communication, the effects on banking communication will also become apparent. The latter can only be avoided if we provide the appropriate financial knowledge, because an application will not explain the basic features of financial products. The 2016 research carried out by the FED reflects on the above, based on the age composition of mobile users, as shown in the figure below. As you can see, young people, the 18 to 29-yearolds, are driving a peek at mobile banking, which supports the above characteristics.

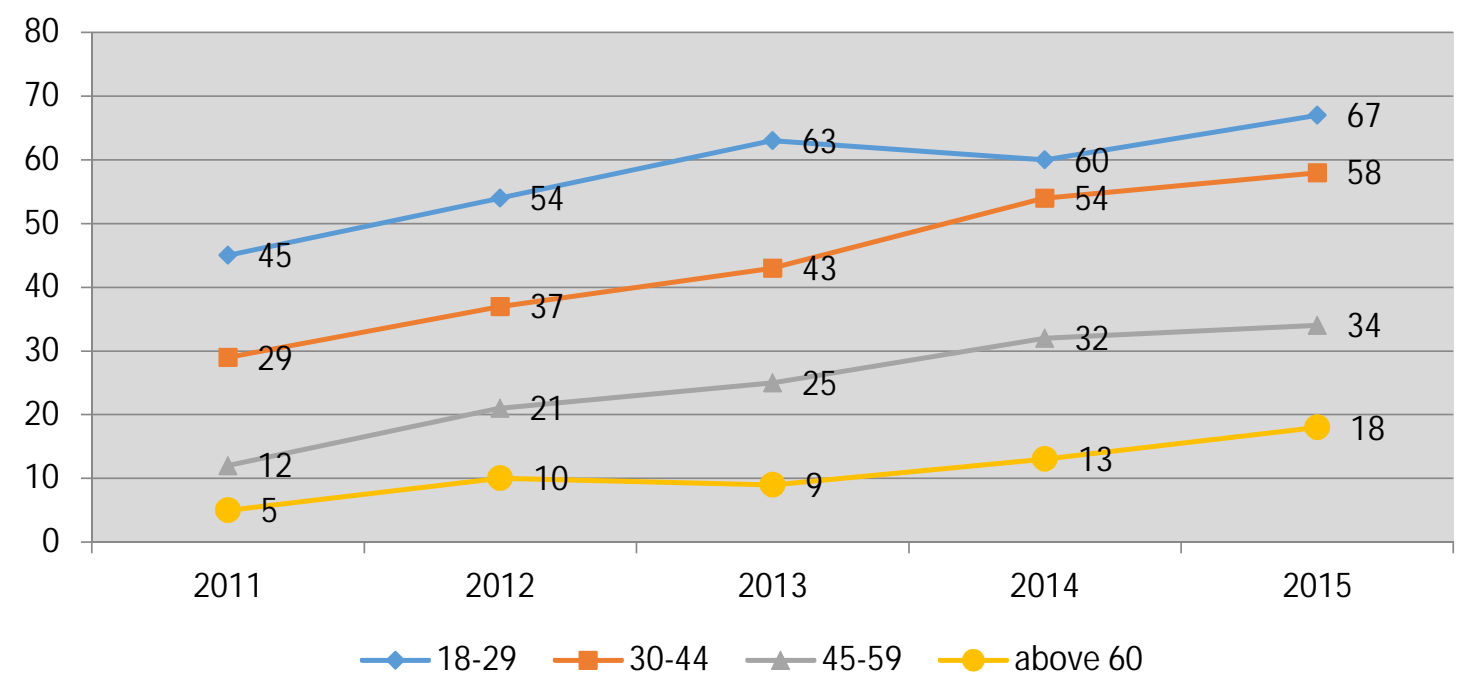

Figure 1: Mobile banking rates (\%) among respondents

Source: FED, 2016 based on own editing

It is not easy to understand the rapidly evolving banking world, and education is not able to keep pace with many innovations and developments, but it may not be its task. The most important mission of the education system would be to provide students financial knowledge in order to avoid financial capital without "munitions".

The development of financial culture and knowledge is the responsibility of financial institutions, which are often part of CSR's activities as part of their activities (Lentner et al., 
Issue no. $27 / 2018$

2015). The development of financial culture as a leader word is always positive, and there are positive examples and initiatives on the topic (bank-organized competitions for general and secondary school students, information publications, series of lectures, etc.), the main thing is that the development of the financial culture of young people is a priority, which can not be done without a prior assessment of their basic knowledge. After the level survey, it would be necessary to develop a strategy with all stakeholders involved (banks, education, government) in order to be able to release prepared, financially not illiterate economic players in the last step of the education system.

\section{Material and method}

The study presents the results of quantitative research focusing on $\mathrm{Z}$ and $\mathrm{Y}$ generations.

In the 2016. year data surveys we conducted a standardized questionnaire survey using the CAPI method. During the recruiting of subjects, a snowball sampling procedure was applied using a single filter of age filtering criterion. As a result of the sampling, a total of 3736 evaluable questionnaires were analyzed using descriptive statistics using factor cluster analysis methods. One of the key objectives of the research was to investigate the hypothesis (H1) that the evaluation of the value of money can be used as a segmentation criterion for young people (H1a), as well as how to manage money (purchase, savings, financial decisions) (H1b). According to our assumption, these two descriptive variables can be differentiated by the diversity of young people and by distinguishing groups that can be well separated from each other. Our other aim was to investigate our hypothesis that there is a detectable relationship (H2) between the clusters that emerge from the two descriptive variables mentioned above. Following the basic concept of value-based consumer stakes models, it is assumed that there is a correlation between the judgment of the value of money and the management of money. That is, the basic context of values-based consumer behavior models is also valid for financial competencies: value orientation of money has an influence on specific decisions on money. 
Issue no. $27 / 2018$

\section{Results of the research}

In order to examine the first hypothesis, we first analyzed the money-related value orientation of the respondents based on the average value of the answers on the Likert scale. In the light of the results we could see that the role of the money's security and the long-term value dimension was the most important of all. On the other hand, tangible goods purchased on money or the social / relationship value of it were not estimated high.

\begin{tabular}{|l|c|}
\hline \multicolumn{1}{|c|}{ Statements } & average \\
\hline Money is important for me, because I can achieve my goals with it & 2,92 \\
\hline Money is important for me, because I can support and help others with it & 2,71 \\
\hline The more money I have, the happier I am & 2,07 \\
\hline Money is worth spending, not saving & 1,95 \\
\hline Money is important, because I can buy things that are needed for my happiness & 2,61 \\
\hline If I have no money, I am more depressed & 2,37 \\
\hline Money gives you a sense of security & $\mathbf{3 , 2 4}$ \\
\hline Money is not as important as free time & 2,75 \\
\hline Money is important for making friends with people who are sympathetic to me & 1,37 \\
\hline Money is value & 2,68 \\
\hline Money is important to save & $\mathbf{3 , 1 7}$ \\
\hline If I need to earn the money, I value it more & $\mathbf{3 , 2 3}$ \\
\hline If I have more money I have more friends & 1,47 \\
\hline If I have money, I'm more valuable & 1,44 \\
\hline A lot of money gives you appreciation & 1,77 \\
\hline Who has money, is always happy & 1,44 \\
\hline Everything can be bought with money & 1,73 \\
\hline
\end{tabular}

Table 1: Evaluating the value of money (average, where $1=$ not at all, $4=$ fully agree)

Source: own research, $2016 \mathrm{~N}=3736$ persons

For the analysis of our first hypothesis, we performed a factor analysis, which resulted in the analysis of a factor structure with different factor numbers. In addition to the statistics index (KMO index and total variance), based on the technical explanation of factor distributions, the four-factor structure was finally considered as the definitive version.

Based on these, we could define the following factor groups: 
Issue no. $27 / 2018$

the value of the money social capital: in this factor the social contacts available by money, the achievement by money

- the factor of goals and happiness by money has been the factors that make it possible to acquire the benefits, feelings of happiness gained through the possession of money.

- the long-term goal of money is the group of factors in which the importance of savings is clearly dominated. The long-term goal orientation, therefore, did not surprisingly have a strong negative relationship with the prevailing factor of money present value.

- the social and alternative benefit group includes social benefits that can be achieved and achievable by money are more preferred alternatives against money.

\begin{tabular}{|c|c|c|c|c|}
\hline Statements & $\begin{array}{l}\text { The value of } \\
\text { the money as a } \\
\text { social capital }\end{array}$ & $\begin{array}{l}\text { The factor of } \\
\text { goals and } \\
\text { happiness by } \\
\text { money }\end{array}$ & $\begin{array}{l}\text { The long-term } \\
\text { goal of money }\end{array}$ & $\begin{array}{l}\text { The social and } \\
\text { alternative } \\
\text { benefit group }\end{array}$ \\
\hline If I have money, I'm more valuable & 0,8448 & 0,1101 & 0,0006 & 0,0062 \\
\hline $\begin{array}{l}\text { If I have more money I have more } \\
\text { friends }\end{array}$ & 0,8008 & 0,0237 & 0,0026 & 0,1002 \\
\hline Who has money, is always happy & 0,7423 & 0,1836 & $-0,0500$ & $-0,0704$ \\
\hline $\begin{array}{l}\text { Money is important for making } \\
\text { friends with people who are } \\
\text { sympathetic to me }\end{array}$ & $\mathbf{0 , 7 2 7 2}$ & 0,0615 & $-0,0646$ & 0,1454 \\
\hline $\begin{array}{l}\text { A lot of money gives you } \\
\text { appreciation }\end{array}$ & 0,7063 & 0,2301 & 0,0905 & 0,0020 \\
\hline $\begin{array}{l}\text { Everything can be bought with } \\
\text { money }\end{array}$ & $\mathbf{0 , 5 5 8 6}$ & 0,2238 & $-0,1229$ & $-0,1824$ \\
\hline $\begin{array}{l}\text { Money is important, because I can } \\
\text { buy things that are needed for my } \\
\text { happiness }\end{array}$ & 0,1749 & 0,7215 & $-0,0747$ & $-0,0570$ \\
\hline Money gives you a sense of security & $-0,0646$ & 0,6814 & 0,1269 & 0,1017 \\
\hline $\begin{array}{l}\text { If I have no money, I am more } \\
\text { depressed }\end{array}$ & 0,2535 & 0,6775 & $-0,0178$ & $-0,0869$ \\
\hline $\begin{array}{l}\text { The more money I have, the happier } \\
\text { I am }\end{array}$ & 0,4109 & 0,6296 & $-0,0530$ & $-0,0613$ \\
\hline
\end{tabular}


Issue no. $27 / 2018$

\begin{tabular}{|l|r|r|r|r|}
$\begin{array}{l}\text { Money is important for me, because } \\
\text { I can achieve my goals with it }\end{array}$ & 0,0806 & $\mathbf{0 , 5 7 5 1}$ & 0,0705 & 0,2539 \\
\hline Money is value & 0,2546 & $\mathbf{0 , 4 1 9 5}$ & 0,3780 & $-0,1403$ \\
\hline Money is important to save & 0,0245 & 0,1357 & $\mathbf{0 , 8 2 9 4}$ & 0,1051 \\
\hline Money is worth spending, not saving & 0,2543 & 0,2742 & $\mathbf{- 0 , 7 0 0 6}$ & 0,1716 \\
\hline $\begin{array}{l}\text { If I need to earn the money, I value } \\
\text { it more }\end{array}$ & $-0,0131$ & 0,1212 & 0,3726 & $\mathbf{0 , 3 3 2 0}$ \\
\hline $\begin{array}{l}\text { Money is important for me, because } \\
\text { I can support and help others with it }\end{array}$ & 0,0331 & 0,0781 & 0,1534 & $\mathbf{0 , 6 8 6 6}$ \\
\hline $\begin{array}{l}\text { Money is not as important as free } \\
\text { time }\end{array}$ & $-0,0009$ & $-0,0722$ & $-0,1632$ & $\mathbf{0 , 6 7 6 9}$ \\
\hline
\end{tabular}

Table 2: Factors based on the judgment of money maturity

Source: own research, $2016 \mathrm{~N}=3736$ persons $K M O=0.853$; all variants value $=53.5 \%$

Cluster internalisation was also performed for each factor, as a result the following groups were distinguished from each other. As a result, we could define four groups:

- $\quad$ The segment of "Underestimates" (962 people), who did not consider each of the factors relevant to the others.

- The group of "Happy because of money" (1109 people), the subjects who surpass the happiness of money, the alternative utility was assessed below.

- "Relationships and savings preferences" (534 people) are respondents for whom the value of money is equivalent to the available relationships and achievable savings.

- For people belonging to the "Do good and live good" segment (1131 people), the social utility of money was the most preferred and at the same time the factor of happiness of the money was considered important. That is, those who seek to achieve their own goals and their happiness while trying to help others so they have a kind of social sensitivity. 
Issue no. $27 / 2018$

\begin{tabular}{|l|r|r|r|r|}
\hline & \multicolumn{3}{|c|}{ Clusters } \\
\hline Factors & $\begin{array}{c}\text { Under- } \\
\text { estimates } \\
\text { because of } \\
\text { money }\end{array}$ & $\begin{array}{c}\text { Relationships } \\
\text { and savings } \\
\text { preferences }\end{array}$ & $\begin{array}{c}\text { Do good and } \\
\text { live good }\end{array}$ \\
\hline The value of the money as a social capital & $-0,7276$ & $-0,0165$ & $\mathbf{1 , 6 2 3 8}$ & $-0,1316$ \\
\hline The factor of goals and happiness by & $-0,8838$ & $\mathbf{0 , 5 6 5 2}$ & $-0,8731$ & $\mathbf{0 , 6 0 9 7}$ \\
\hline The long-term goal of money & $-0,3745$ & 0,0587 & $\mathbf{0 , 6 2 3 4}$ & $-0,0334$ \\
\hline The social and alternative benefit group & 0,0395 & $\mathbf{- 0 , 9 3 9 6}$ & 0,1182 & $\mathbf{0 , 8 3 1 8}$ \\
\hline
\end{tabular}

Table 3: Segments based on the value of money

Source: own research, $2016 \mathrm{~N}=3736$ persons

In order to examine the different financial decision segments, we have also analyzed the results of this issue in several stages. this time, we also examined the financial value of some financial decisions and the way the money was handled among young people. Based on the results, we could see that the most characteristic aspect of the interviewees is on the one hand price awareness and, on the other hand, the orientation of the financial decisions that prove the strength of the cognitive part of attitudes. In the field of money management, security is the dominant pursuit, and the desire to save is strong, which most people follow as a behavioral attitude from home. The valuation of the present value of money is not just as representative of the pattern as it is the source of external sources of information on financial products, and confidence in advertisements.

Overall, we could see that the pursuit of security, long-term value orientation, the importance of price and the pursuit of decisions based on financial issues generally characterize the pattern.

\begin{tabular}{|l|r|}
\hline \multicolumn{1}{|c|}{ Statements } & average \\
\hline If I make a financial decision, I always get informations about it & 3,33 \\
\hline When making financial decisions, the opinions of my family/close friends are the most important & 2,81 \\
\hline $\begin{array}{l}\text { I try to rely on external sources of information (consultants, business news portalts, etc.) on } \\
\text { financial issues }\end{array}$ & 2,59 \\
\hline
\end{tabular}


Issue no. $27 / 2018$

\begin{tabular}{|l|r|}
\hline I always handle my finances at the same bank & 2,93 \\
\hline I trust in advertisements promoting financial products & $\mathbf{1 , 5 2}$ \\
\hline I always monitor my finances & $\mathbf{3 , 0 7}$ \\
\hline I'd rather spend my money than saving & $\mathbf{1 , 9 8}$ \\
\hline My current money is worth more than the future money (which I save) & 2,17 \\
\hline I'm willing to risk part of my money if it's a high-income investment & 2,26 \\
\hline I wouldn't put my money in the long run, because I do not trust the banks & 2,37 \\
\hline If I buy, I'll check the prices & $\mathbf{3 , 5 6}$ \\
\hline If I can, I'll save by choose worse quality but cheaper things & 2,32 \\
\hline I'd rather buy more expensive but more durable things & 2,95 \\
\hline I try not to spend all my money but also save some & $\mathbf{3 , 3 1}$ \\
\hline My parents are always saving & $\mathbf{3 , 1 4}$ \\
\hline We discuss common purchasing decisions in the family & 2,89 \\
\hline I think that is the best decision, that who earns the money makes the choices & 2,51 \\
\hline When purchasing we always pay attention to the actions & 3,13 \\
\hline I buy things when they are at discounts & 2,13 \\
\hline I usually buy more than one from the promotion items & 2,39 \\
\hline
\end{tabular}

Table 4: Financial decisions, judgment of money handling in the sample (average, where $1=$ none at all, $4=$ fully characteristic)

Source: own research, $2016 \mathrm{~N}=3736$ persons

As a second step, using factor analysis, we were curious about how the individual factors are related to what young people think. This time, we also analyzed several factor structures with different factor numbers, and in addition to statistical indexes (KMO index and total variance), a professional explanation of factor distributions helped to select the final structure, which resulted in seven factors being defined:

- Factor of orientation and safety, which included factors such as price tracking, buying decision making the decisive role of the price, and seeking to save and security.

- Actions and discounts factor, where buying behaviors favoring actions and discounts were grouped together. 
Issue no. $27 / 2018$

- „Live for today" the factor that prefers the present value, which is characterized by the dominance of behavior that prefers the present value of money instead of longterm financial commitments and savings.

- „Cheap, even if it's worse" price sensitivity factor, which has a strong negative relationship with the more expensive, but the better choice for buying a product. This factor group is characterized by the preference favoring the lower price, even at the expense of quality.

- In the social background and security factors are in which the pursuit of family financial behaviors is dominant and at the same time has a strong negative relationship with the financial risk taking behavior.

- Risk mitigating factors have been included in this group, such as parent councils, follow-up behavior, and brand loyalty, loyalty (the choice of the same bank) with regard to financial decisions.

- Factor of advertising and external information, where outsourcing of external sources of information is dominated by external reference personal preference decision types.

\begin{tabular}{|c|c|c|c|c|c|c|c|}
\hline Statements & 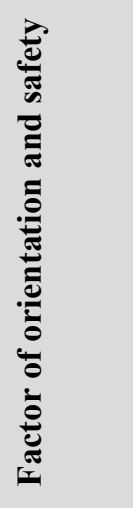 & 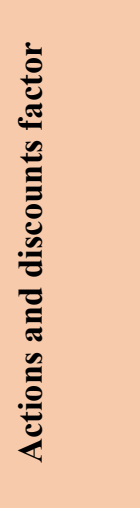 & 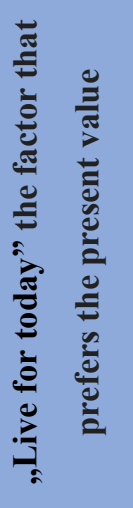 & 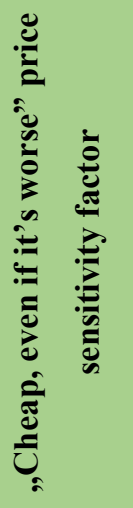 & 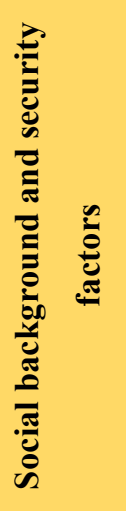 & 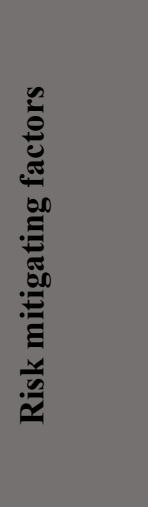 & 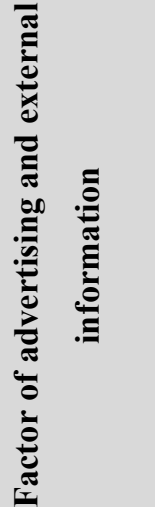 \\
\hline $\begin{array}{l}\text { If I make a financial decision, I always get } \\
\text { informations about it }\end{array}$ & 0,6873 & $-0,0219$ & $-0,0235$ & $-0,0513$ & 0,2114 & $-0,0637$ & 0,1105 \\
\hline I always monitor my finances & 0,6628 & 0,0540 & 0,0384 & $-0,0507$ & $-0,1029$ & 0,0174 & 0,0664 \\
\hline $\begin{array}{l}\text { I try not to spend all my money but also save } \\
\text { some }\end{array}$ & 0,6062 & 0,0693 & $-0,2495$ & $-0,0342$ & 0,1786 & 0,1912 & $-0,0899$ \\
\hline
\end{tabular}


On-line Journal Modelling the New Europe

Issue no. $27 / 2018$

\begin{tabular}{|c|c|c|c|c|c|c|c|}
\hline If I buy, I'll check the prices & 0,4995 & 0,2396 & 0,0193 & 0,1796 & 0,1996 & 0,0941 & $-0,3913$ \\
\hline I buy things when they are at discounts & $-0,0341$ & $\mathbf{0 , 7 8 3 6}$ & 0,0853 & 0,1342 & 0,0803 & $-0,0009$ & 0,1441 \\
\hline $\begin{array}{l}\text { I usually buy more than one from the } \\
\text { promotion items }\end{array}$ & 0,0285 & 0,7751 & 0,0422 & 0,0380 & $-0,0185$ & 0,0429 & 0,0765 \\
\hline $\begin{array}{l}\text { When purchasing we always pay attention to } \\
\text { the actions }\end{array}$ & 0,2774 & 0,6449 & $-0,0458$ & 0,1303 & 0,2500 & 0,1387 & $-0,1616$ \\
\hline $\begin{array}{l}\text { I wouldn't put my money in the long run, } \\
\text { because I do not trust the banks }\end{array}$ & 0,1260 & $-0,0092$ & 0,7150 & 0,0207 & 0,0281 & $-0,0317$ & $-0,2082$ \\
\hline $\begin{array}{l}\text { My current money is worth more than the } \\
\text { future money (which I save) }\end{array}$ & $-0,0575$ & 0,0589 & 0,6714 & 0,0095 & 0,0098 & 0,0326 & 0,2076 \\
\hline I'd rather spend my money than saving & $-0,3588$ & 0,0797 & 0,6258 & $-0,0476$ & $-0,1040$ & 0,0344 & 0,1937 \\
\hline $\begin{array}{l}\text { I'd rather buy more expensive but more } \\
\text { durable things }\end{array}$ & 0,1453 & $-0,0275$ & 0,1153 & $-0,8604$ & 0,0354 & 0,1027 & 0,0276 \\
\hline $\begin{array}{l}\text { If I can, I'll save by choose worse quality but } \\
\text { cheaper things }\end{array}$ & 0,0656 & 0,2668 & 0,1287 & 0,8166 & 0,0173 & 0,1406 & 0,0259 \\
\hline $\begin{array}{l}\text { We discuss common purchasing decisions in } \\
\text { the family }\end{array}$ & 0,2520 & 0,1653 & 0,0620 & $-0,0809$ & 0,6689 & 0,0019 & 0,1101 \\
\hline $\begin{array}{l}\text { I'm willing to risk part of my money if it's a } \\
\text { high-income investment }\end{array}$ & 0,3075 & 0,0381 & 0,3289 & $-0,0765$ & $-\mathbf{0 , 5 8 0 7}$ & 0,1379 & 0,1848 \\
\hline My parents are always saving & 0,2892 & 0,1477 & 0,0552 & $-0,0470$ & 0,4644 & 0,2490 & $-0,0848$ \\
\hline $\begin{array}{l}\text { I always handle my finances at the same } \\
\text { bank }\end{array}$ & 0,0173 & $-0,0450$ & $-0,0396$ & 0,0166 & 0,1452 & 0,6936 & 0,0921 \\
\hline $\begin{array}{l}\text { I think that is the best decision, that who } \\
\text { earns the money makes the choices }\end{array}$ & 0,0137 & 0,2297 & 0,0794 & $-0,0736$ & $-0,2139$ & 0,6424 & $-0,0693$ \\
\hline $\begin{array}{l}\text { When making financial decisions, the } \\
\text { opinions of my family/close friends are the } \\
\text { most important }\end{array}$ & 0,1278 & $-0,0247$ & $-0,0047$ & 0,1794 & 0,4407 & 0,5100 & 0,1365 \\
\hline $\begin{array}{l}\text { I trust in advertisements promoting financial } \\
\text { products }\end{array}$ & $-0,1213$ & 0,1916 & 0,1673 & 0,0495 & $-0,0435$ & 0,2860 & 0,6836 \\
\hline $\begin{array}{l}\text { I try to rely on external sources of } \\
\text { information (consultants, business news } \\
\text { portalts, etc.) on financial issues }\end{array}$ & 0,4247 & 0,0212 & 0,0227 & $-0,0179$ & 0,1043 & $-0,1198$ & 0,6190 \\
\hline
\end{tabular}

Table 5: Factors for money-related decisions

Source: own research, $2016 \mathrm{~N}=3736$ persons $K M O=0.727$ total variance: $57.8 \%$ 
Issue no. $27 / 2018$

For the hypothesis, clusters were analyzed for the factors to see how the sample could be segmented according to how the financial decisions were made. As a result of the Kmeans clustering process we could characterize seven target groups: -

- "Price sensitives" (648 people) for whom the criterion of cheapness is most important when making a decision, even if the low price preference equals worse quality

- $\quad$ "Action hunters" (572 people) who valued the actions and discounts factor.

- $\quad$ "Conscious information finders" (644 people), who are oriented towards tracking prices, price preference, and trying to save money and increase their sense of security. It is interesting, however, that risk mitigation solutions (such as brand loyalty or parental pattern tracking) are not explicitly specific to them. They are likely to be consumers who are more likely to be characterized by an individual decision, relying on themselves and on their own information in the absence of family behavior patterns.

- "Non-preferentials" (443 people) who do not evaluate a single factor over the rest of the group. Presumably, the unmatched value system, the unclear preference system, is behind the uncertain behavior that is unaware of the significance of a single factor group.

- „Live for today advertisements followers” (379 people), who rely on external sources of information instead of social model monitoring, they estimate the benefits of money currently more than investments and savings.

- "Risk reducing consumers" (557 people) who want to reduce the risk of financial decision making by branding (choosing the same financial institution) and listening to parental opinions. For this segment, the primary reference people are the parents, which is very important information from a communication point of view. The other their advantage for financial service providers - is loyalty, that is, they are willing to be loyal to a financial institution, which is a particularly perceived consumer character for the $\mathrm{Y}$ and $\mathrm{Z}$ generations that we know are extremely difficult to win.

- „Traditional segment seekers” (493 people), who are familiar with family-based decision-making on financial issues, saving as a parental example to be followed. At 
Issue no. $27 / 2018$

the same time, they reject any risky financial decision even if they are more beneficial.

\begin{tabular}{|c|c|c|c|c|c|c|c|}
\hline \multirow[b]{2}{*}{ Factors } & \multicolumn{7}{|c|}{ Clusters } \\
\hline & 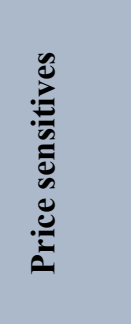 & 选 & 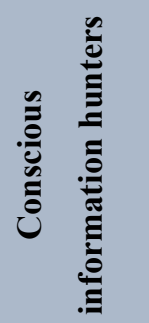 & 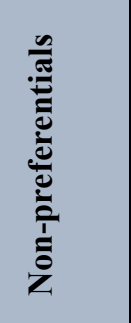 & 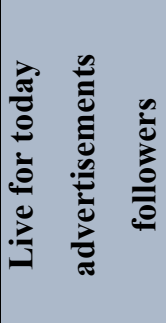 & 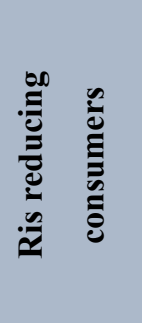 & 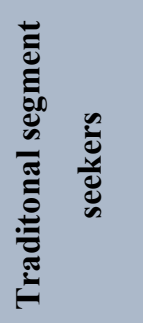 \\
\hline Factor of orientation and safety & 0,3741 & $-0,2984$ & 0,7307 & $-1,4202$ & $-0,1924$ & 0,4494 & $-0,1837$ \\
\hline Actions and discounts factor & $-0,1662$ & 0,9700 & 0,0899 & $-0,3841$ & 0,5784 & $-0,5109$ & $-0,5467$ \\
\hline $\begin{array}{l}\text { "Live for today" the factor that } \\
\text { prefers the present value }\end{array}$ & $-0,4993$ & $-0,3691$ & $-0,4258$ & $-0,5004$ & 0,9968 & 0,2262 & 1,0685 \\
\hline $\begin{array}{l}\text { „Cheap, even if it's worse” } \\
\text { price sensitivity factor }\end{array}$ & 1,0339 & $-0,4219$ & $-0,4181$ & $-0,0292$ & 0,1412 & $-0,4684$ & 0,1236 \\
\hline $\begin{array}{l}\text { Social background and security } \\
\text { factors }\end{array}$ & 0,3749 & 0,3741 & 0,0371 & $-0,4366$ & $-0,2163$ & $-1,0235$ & $\mathbf{0 , 7 3 9 8}$ \\
\hline Risk mitigating factors & 0,4998 & 0,4461 & $-1,0661$ & $-0,3391$ & 0,4731 & $\mathbf{0 , 5 7 5 7}$ & $-0,4913$ \\
\hline $\begin{array}{l}\text { Factor of advertising and } \\
\text { external information }\end{array}$ & 0,0015 & $-0,4969$ & 0,2157 & 0,3403 & 1,5008 & $-0,5565$ & $-0,5380$ \\
\hline
\end{tabular}

Table 6: Consumer segments based on money-related decisions

Source: own research, $2016 \mathrm{~N}=3736$ persons

Based on both descriptive variables (value of money and money-related decisions), we could characterize segments, meaning that the two variables could be used as a segmentation knowledge to characterize consumer groups. Based on the results, H1 hypothesis (H1a and H1b) was accepted.

The second hypothesis was intended to demonstrate the relationship between the segments created by the two descriptive variables.

The Khi-square exams for the clusters were Pearson's significance of 0,000 , which proved that the two variables were not independent from one another ( $\mathrm{H} 2$ proved to be true). 
Issue no. $27 / 2018$

For the analysis of the internal contexts, the adjusted standardized residual value was used. Thereby, we have made the following observations:

Among those who are "pricey" in the financial decision-making (ie the price is being judged and decide on this, even at the expense of quality) compared to the expected value, a greater number of people are who, based on their value system, think money equals happiness. Compared to the expectations, there are fewer "factor of orientations and savings" and „price sensitives”. Among the "Action Hunters", also the money-happy segment was present in a larger proportion than expected. This means that for these two groups (price sensitivities and action hunters) when buying a cheaper product, the ultimate benefit is saving money because money as a target value means happiness for them.

"Conscious information seekers" are consumers who rely on themselves and themselves by relying on financial decisions in the absence of family behavior patterns.

Thus, it is not surprising that we have found a smaller proportion of people who prefer relationship and savings than we have expected. The group of people who are "do good live good" is, however, in a larger proportion than the expectation, which shows that this group, which has a personal choice in its own decisions, is also socially sensitive.

Therefore, they do not follow a family behavior pattern or rely on the opinions of their family members because of their preference for individualism and individual target values. According to their values, they are sensitive to social issues and to help others. From a communicative point of view, it is important that they are consumers who are likely to follow a credible, value-conscious viewer who could not be found in their own social environment.

It is interesting to note that in the "Non-Preferential" the "Underestimates" showed a greater presence than expected, which shows that consumers who make decisions in the absence of a mature value order can be easily influenced. Developing financial awareness, shaping the attitude of money, especially in the cognitive part, can be a priority task. The higher-than-expected rate of "Underestimates" in the "Traditional segment seekers" also shows that security search and the pursuit of traditions can be explained by the lack of immeasurable individual preferences. Forming and developing financial culture can also be a priority for this group. 
Issue no. $27 / 2018$

The „Live for today advertisements followers"Who spend the money more than saving their money and relying on external information and advertising in their decisions, all segments of the value of the money were judged to be lower than expected, except for those who prefer relationships and savings. They are the consumers for whom the value of money is equivalent to the available relationships and the assets that can be purchased from them. This segment is explicitly characterized by demonstrative purchases, that is to say, the availability of goods available for the money, the social, and the relationship benefits.

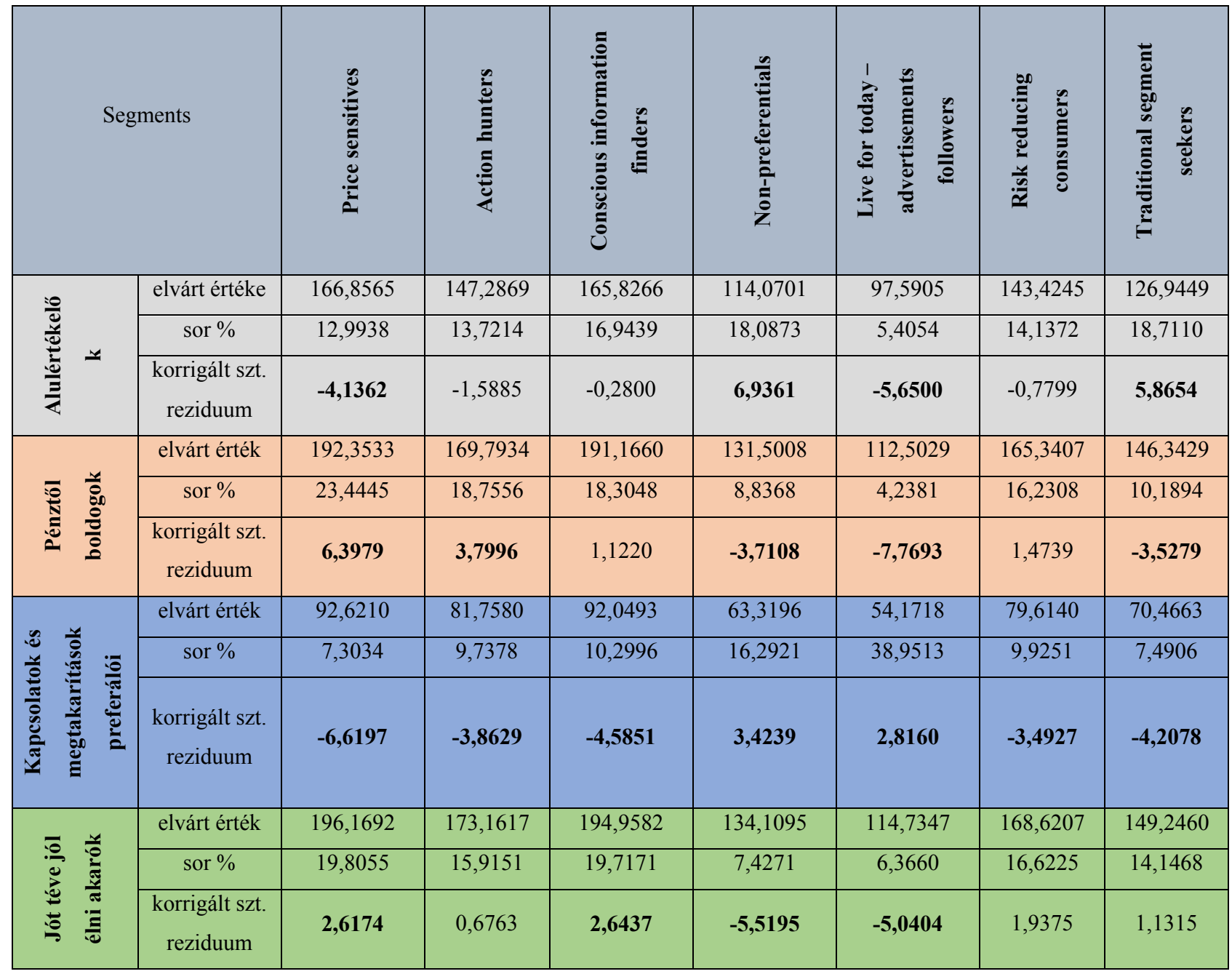

Table 7: Relationship between outlined segments of the value of money and customer segments based on money-related decisions

Source: own research, $2016 \mathrm{~N}=3736$ persons; sig $=0.000$ 
Issue no. $27 / 2018$

\section{Conclusions}

In the present study, based on the baseline of value-based consumer behavior theories, we used the generation marketing approach to examine the value system of young people regarding the judgment of money and how to make decisions about money, and the two descriptors of the relationship between the two descriptive variables.

One of the key objectives of our research was to demonstrate that value judgments and money management can be used as a segmentation criterion among young people ( $\mathrm{H} 1 \mathrm{a}$, H1b). In our view, these two descriptive variables indicate that the plurality of young people can be well differentiated and that clearly distinguishable clusters can be defined.

Our other aim was to demonstrate the relationship between the judgment of the value of money and the way in which money management and financial decision can be made (H2). That is, the basic context of value-based consumer behavior theories are also valid for money-related decisions. Quantitative research was used for hypothesis studies, in which 3736 evaluable questionnaires were analyzed. During the sampling we used the snowball method to recruit the subjects.

In order to look at the values and the decisions on money, these different segments are drawn up, we have analyzed these issues in several steps. Factor and K-means cluster analysis were performed. As a result of the research, both groups of descriptors were able to characterize consumer groups. In the value of money, we could define four segments: "Underestimates" who did not consider a single factor more important than other segments. The group of "Happy because of money", for whom the possession of money means happiness. "Who prefers Contacts and Savings", which reviewed the social benefits of money and ultimately the segment of "Do good live good" who want to help others by having the money.

With money management and decision-making, seven groups - "Price Sensitive", for whom the criterion of cheapness is the most important, the "Action Hunters" who reviewed the actions and discounts factor. The „Conscious Information Finders" to whom price orientation, price tracking, price preference were characteristic, „Non-Preferentials”, who did not evaluate a single factor over the rest of the groups. In addition, we defined the group of. Live for today advertisements followers", who rely on external sources of 
Issue no. $27 / 2018$

information instead of social model monitoring to make their financial decisions, „Risk reducing consumers" "Who want to reduce the risk of their financial decision by following the parental opinion and choosing the same financial institution and finally the Traditional segment seekers", who were characterized by family common decision-making and parental behavior.

In the light of the results, H1a and H1b hypotheses were accepted.

In the second phase of our research we analyzed the correlation between the above mentioned segment. The Khi-square exams for clusters were Pearson's significance of 0,000, which proved that the two variables were not independent of each other. With this, our $\mathrm{H} 2$ hypothesis was accepted.

The internal correlation between the segments was examined on the basis of the corrected standardized residual value. During the technical analysis of the relationship between the value system and the financial decision-making group, we could see that segments ("Non-Preferentials", "Underestimates") are characterized by unmatched value system and preference system. They are the ones who need to concentrate on the cognitive stage of their attitude towards money by educating campaigns to raise their financial awareness.

We could also define segments ("Concious information finders", "Do good live good") who, with a mature decision, but with a strong social sensitivity, could use it as a reference person in communication with financial awareness. In addition, we were able to characterize segments ("Traditional segment seekers") who are dominated by the social, family background, and the follow-up of parental behavior. In their case, parents are the target group in communication, as their views are relevant to young people in financial decisions. In our view, the results can provide support to financial service providers for getting acquainted with their potential target groups and for educational professionals involved in the development of financial culture. In the continuation of our research we plan on the socio-demographic characterization of each segment to get a more subtle picture of each target group, supporting a more accurate target group-oriented strategic planning. 
Issue no. $27 / 2018$

\section{Literature background}

- ALI, B.; SZIKORA, P. (2017): Az Y generáció és az internet kapcsolata Vállalkozásfejlesztés a XXI. században VII. tanulmánykötet, Budapest, Óbudai Egyetem, pp.11-24. (Hungarian)

- ANDROKA, R. (2003): Bevezetés a szociológiába. Budapest: Osiris Kiadó 648. pp. (Hungarian)

- ATKINSON, A.; MESSY, F.A. (2012): Measuring Financial Literacy, OECD Working Papers on Finance, Insurance and Private Pensions No. 15, http://www.oecdilibrary.org/docserver/download/5k9csfs90fr4-, en.pdf? expires $=1498684984 \& \mathrm{id}=\mathrm{id} \&$ accname $=$ guest $\&$ checksum $=\mathrm{C} 5 \mathrm{~B} 34 \mathrm{DF} 2381775999$ E9EFC9A4A5B956D, dowwnloaded: 2016.08.04.

- BALÁZSNÉ LENDVAI, M. (2013): A bankmarketing szerepe a pénzügyi kultúra fejlesztésében, Doktori Ph.D. értekezés, Nyugat-Magyarországi Egyetem, Sopron, http://ilex.efe.hu/PhD/ktk/balazsnelendvai/disszertacio.pdf, letöltve: 2016.10.05.

- BÁRCZI J.; ZÉMAN Z. (2015): A pénzügyi kultúra és annak anomáliái, Polgári szemle, vol. 11, no. 1-3., pp. 101-108. (Hungarian)

- BÉRES, D.; HUZDIK, K. (2012): A pénzügyi kultúra megjelenése makrogazdasági szinten, Pénzügyi Szemle, vol. 57, no. 3, pp. 322-336. (Hungarian)

- CSISZÁRIK-KOCSIR, Á. (2016): Etikus pénzügyek, avagy a pénzügyek etikája Vélemények egy kutatás eredményei alapján, Polgári Szemle, vol. 12., no. 4-6, pp. 32-44 (Hungarian)

- Federal Reserve /FED/ (2016): Consumers and Mobile Financial Services 2016, https://www.federalreserve.gov/econresdata/consumers-and-mobile-financial-servicesreport-201603.pdf, downloaded: 2018.01.02.

- GRIFONI, A.; MESSY, F.A. (2012): Current Status of national Strategies for Financial Education; a comparative analysis and relevant practices, OECD Working Papers on Finance, Insurance and Private Pensions, No. 16.

- GIDDENS, A. (1990): The Consequences of Modernity, Cambridge, Polity Press 
- HAWKINS, D.; BEST, R.; CONEY, K. (1992): Consumer Behavior 5th ed. Irwin, Boston M.A.

- HOFMEISTER-TÓTH, Á. (2003): Fogyasztói magatartás, Budapest: Aula Kiadó 325. pp. (Hungarian)

- HORVÁTH, Á. (1996): A fogyasztói magatartás és az élelmiszerfogyasztás jellemzői. (PhD) Doktori értekezés, GATE, Gödöllő, (Hungarian)

- JOHNSON, E.; SHERRADEN, M.S. (2007) From financial literacy to financial capability amog youth, Journal of Sociology and Social Welfare, vol. 34, no. 3, pp. 119-145.

- KAHLE, L.R.; BEATTY, S.E.; HOMER, P.E. (1986): Alternative Measurement Approaches to Consumer Values: The List of Values (LOV) and Values and Lifestyles (VALS), Journal of Consumer Research. Vol. 13, no. 3., pp. 405-409.

- KERÉNYI, Á.; MOLNÁR, J. (2017): A FinTech-jelenség hatása - Radikális változás zajlik a pénzügyi szektorban?, Hitelintézeti Szemle, vol. 16, no. 3, pp. 32-50. (Hungarian).

- KLAPPER, L.; LUSARDI, A.; PANOS, G.A. (2012): Financial Literacy and the Financial Crisis. Policy Research Working Paper. Washington, The World Bank.

- KOH, N.K.; LEE, C.B. (2010): “Because My Parents Say So”- Children's monetary decision making, Procedia Social and Behavioral Sciences, vol 9, pp. 48-52.

- LEHOTA, J. (szerk.) (2001): Élelmiszergazdasági marketing, Budapest: Müszaki Kiadó 323 pp. (Hungarian)

- LENTNER, CS.; SZEGEDI, K.; TATAY, T. (2015): Társadalmi felelősségvállalás a bankszektorban, Pénzügyi Szemle, vol. 60, no. 1, pp. 96-104. (Hungarian)

- LUKSANDER, A.; BÉRES, D.; HUZDIK, K.; NÉMETH, E. (2014): A felsőoktatásban tanuló fiatalok pénzügyi kultúráját befolyásoló tényezők vizsgálata, Pénzügyi Szemle, vol. 59, no. 2, pp. 237-258. (Hungarian)

- Magyar Nemzeti Bank - Pénzügyi Szervezetek Állami Felügyelete (2008): Együttmüködési megállapodás a pénzügyi kultúra fejlesztés területén, 
https://www.mnb.hu/letoltes/0415mnbpszafmegallpodas-penzugyi-kultura-fejleszte.pdf, downloaded: 2012.04.12., (Hungarian)

- MENON, RAVI (2016): Singapore's FinTech journey - where we are, what is next, FinTech Conference, Singapore, 16 November 2016, http://www.bis.org/review/r161118a.htm. downloaded 2017.11.24.

- OECD (2016): OECD/INFE International Survey of Adult Financial Literacy Competencies.

- OSANA, H.P.; TUCKER, B.J.; BENNETT, T. (2003): Exploring adolescent decision making about equity: Ill-structured problem solving in social studies. Contemporary Educational Psychology, vol. 28, pp. 357-383.

- SCHEWE, C.D.; NOBLE, S.M. (2000): Market Segmentation by Cohorts: The Value and Validity of Cohorts in America and Abroad, Journal of Marketing Management, vol. 16, no. 1-3, pp. 129-142.

- STRAUSS, W.; HOWE, N. (1992): Generations: The History of America'sFuture, 1584 to 2006, New York: Harper Perennial.

- SUGANYA, S.; SAKTHIVELRANI, S.; DURAI, K. (2013): Development and validation of financial literacy scale, International Journal of Research in Commerce and Management, vol. 4. , no. 1, pp. 99-104.

- TÖRÖCSIK, M.; SZÜCS, K.; KEHL, D. (2014): Generációs gondolkodás - A Z és az Y generáció életstílus csoportjai, Marketing \& Menedzsment, II. különszám, pp. 3-15.

- VERES, Z. (2004): Marketingkutatási eredmények a fogyasztásszociológiában A Szociális identitás, az információ és a piac, SZTE Gazdaságtudományi Kar Közleményei, Szeged, Jatepress, pp. 282-296. (Hungarian)

- ZSÓTÉR, B.; NAGY, P. (2012): Mindennapi érzelmeink és pénzügyeink, Pénzügyi Szemle, vol. 57, no. 3., pp. 310-321. (Hungarian) 